By FELIX REICHMANN

\title{
The Acquisition Librarian as Bibliographer
}

Dr. Reichmann is assistant director, Cornell University Library.

$\mathrm{E}$ VERY SCHOLARLY activity, both in the sciences and the humanities, is based on the exact observation and the minute description of all pertinent phenomena. Seen in terms of the history of scholarship the origin is often a mere listing of facts, then the material is carefully described and classified according to certain characteristics. Finally critical methods of research are used to analyze the individual forms and trace their developments.

The discipline which investigates the book as a physical witness in the court of cultural history follows the above pattern. Bibliography, which originally meant the writing of books, is now understood to be primarily interested in the material aspects of a publication. The evaluation of the content is left to other branches of learning; here bibliography has only an ancillary function. Its main objectives are the listing of titles and a critical investigation of their physical appearance.

Systematic bibliography, to accept Theodore Bestermann's terminology, ${ }^{2}$ enumerates titles and arranges them according to some selected principle: the author, printer or publisher, a subject, a time period, or a place. Critical bibliography is the analysis of an individual publication or copy on a comparative and historical basis. Such an investigation presupposes a detailed knowl-

\footnotetext{
${ }^{1}$ Paper presented at the meeting of the University Libraries Section, A.C.R.L., Jan. 21, 1949, Chicago.

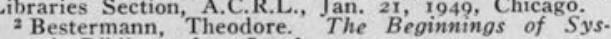
tematic Bibliography. London, 1935.
}

edge of the history of publishing and book distribution in a given period. "It includes every incident, mishap or change of policy which may occur in the life of the book." ${ }^{3}$

Three points in this brief description of bibliography bear directly on the general theme of this paper: $\mathrm{I}$. Bibliography tends to be catholic; at least three of the five main criteria for a systematic bibliography, grouping according to the printer, a time period or a place, cut across subject departmentalization. 2. Bibliography has a service function; it does not organize knowledge itself, but groups the records of knowledge for the use of the subject specialist. 3. It is intimately linked with the history and technique of book production and distribution.

Some of the most important aspects of librarianship are cognate to these principles. J. Christian Bay has well described its basic ideology as "human enlightenment in a historical continuity." ${ }_{4}$ It disregards by definition all subject boundaries and serves with equal zeal all branches of knowledge and all types of human beings. Its primary purpose is to organize the records of knowledge and to marshal the physical witnesses of human thought. Manifold are the ties between librarianship and the book trade in all its phases. We cannot attain a mutually satisfactory relationship with our most substantial supplier unless we fully understand his problems and difficulties. Not only are the two professions linked

\footnotetext{
${ }^{3}$ Sadleir, Michael. "Bibliographical Study of Books of the XIXth Century," in The Bibliographical So.

ciety, $1892 \cdot 1942$. London, 1945 . the Librarian," in The Fortune of Books. Chicago, 1941 .
} 
in one economic situation, but they also have so many similar objectives and activities that a discussion of the book trade finds its legitimate place in every broader treatment of librarianship. Lastly, bibliography is our cardinal tool, essential for many of our activities in all departments of the library. It is indispensable in book selection, in identifying a given title, in collating a given copy and it is vital in cataloging and reference.

The librarian as buyer, the great book collector and the bookminded subject specialist have much in common. Their buying activities directed by a knowledge of systematic and critical bibliography are rarely in competition but tend to supplement each other.

Michael Sadleir's witty definition of the connoisseur fits all three of them. "In nature the bird who get up earliest catches the most worms, but in book collecting the prizes fall to birds who know worms when they see them." 5 Their judgment of a title or a copy is in many cases an identical one, but their decision for an actual purchase may vary because their motivations for buying are different. The private collector buys an item because he wants it, because it fits in with his aesthetic and literary tastes, because he enjoys the possession of a coveted book. He will be guided by his bibliophile enthúsiasm; after the necessary critical evaluation of the copy has been satisfied by proper bibliographical identification, the final decision can be made on an emotional basis. The collector buys for himself and he will be forever identified with the great collection he has accumulated. The acquisition librarian buys a title because he assumes that somebody else will need the book and will use it. He will attempt to listen to cool reasoning only and will not permit the question: How

s Sadleir, Michael. "Decentralization or Deadlock." Colophon, no. $3,1930$. much do I like this book? His criteria will be: I. Who within the framework of my institution and its possible extension will benefit by this book? 2. What is the priority of this acquisition seen from the point of view of my budget limitations? He will remain anonymous; what scholarship he has, what bibliographical knowledge he has acquired will be expressed in his book selection.

Both collector and librarian will be much interested in the question of bibliographical rarity and will agree theoretically at least, that the qualifications for "rare" are hard to find and worthwhile to be searched for. The librarian, however, will emphasize the second quality more than the first. He will request that the given bibliographical "point" be a truly significant one, a potential source for thinking and research. For instance, the cancel replacing page 302 in Vol. II of Boswell's Johnson (I79I) is of great interest because it substitutes a tampered text for Johnson's original, rather free remarks on marital infidelity. The misprint "Parllelen" instead of "Parallelen" on the title page of Saur's first Bible (Philadelphia I 743) is significant because it is a characteristicon for the second printing of the title page; the particular circumstances, which had necessitated a hasty reprint of the title page and therefore had caused this misprint, have a documentary value for the religious history of the colonial Pennsylvania Germans. ${ }^{6}$ The librarian will agree that blank pages which are part of a signature (as in Schedel's Weltchronik of 1493, in Chapman's Homer of I6I6 and in scores of similar examples) form an integral part of a complete copy, but he may buy it nevertheless, after having deducted the necessary discount of the price. But if advertisements do not form

- Reichmann, Felix. Christopher Sower, Sr., 16941758 , an Annotated Bibliography. Philadélphia, 1943. Items 42 and $42 \mathrm{a}$. 
part of the signatures he may well disregard their absence as well as all the points which Newton has aptly called "pseudo bibliography". 7 And lastly, he will do well to remember Lord Chesterfield's antibibliophile remarks: "The best books are the commonest and the last editions are always the best."

The question whether the subject specialist on the faculty or the acquisition librarian should have formal responsibility for the upkeep of the book collection has been hotly debated. Today many European libraries charge the professional library staff with the book selection; a corresponding trend among American institutions has been rather slow in developing. This question, like so many similar ones, can only be argued on the basis of satisfactory performance. An acquisition librarian who leisurely wears the cloak of professional dignity instead of working with his bibliographical tools will not do.

One argument for the centralization of book selection within the library is the oneness of knowledge. Subject departmentalization is a necessary administrative device, a kind of working hypothesis, but in the last analysis all learning forms an indivisible unity. Item $\mathrm{I}$, in a bibliography of English literature chronologically arranged according to imprint dates would be a good example for the overlapping of subject fields. This title would be in Latin, have as author a church father, carry an Italian imprint and be manufactured by a German printer. And all this together is the correct entry for the first appearance in print of an English author. The Dissuasio Valerii ad Rufinum ne uxorem ducat, a famous English XIII century tirade against marriage, is without any doubt the work of Walter Map. By some curious mistake of a mediaeval scribe, this short piece, possibly in view of its episto-

T Newton, A. E. Bibliography and Pseudo Bibliog. raphy. Philadelphia, 1936. lary form, was included in a manuscript containing the letters of St. Jerome. This mistake escaped the attention of several scribes and also of some XV century printers. Among those who included Walter Map in their edition of the Epistolae S. Hieronymi were the two German printers Sweynheym and Pannartz who printed the first edition of the Epistolae, Rome, $1468 .^{8}$

The principle of central administration for the university's book collection is generally accepted. The administration of book selection, the most noble function of the library, should follow the same pattern. Although we acquire books individually, title by title, we select in terms of the collection as a whole. Book selection forms an integral part of a number of technical operations which are performed in the university library and should therefore remain in the appropriate administrative unit of the library. A title, which has been tentatively selected, must be bibliographically identified and searched in the catalogs and records of the acquistion department. The information thus gained is used for preliminary cataloging, for the collating of the copy when received, and it forms the substance for the final catalog entry. Lastly, every purchase is a straight business operation regardless of the high scholarly level which may have initiated the selection. Like an investment banker we operate with money which is not ours and have the obligation to use it to the best advantage in terms of the market possibilities. Book prices are flexible and the so called correct price must be calculated as a statistical average from dealer catalogs and auction reports. Book dealers rarely fit in academic subject departmentalization and only a central selecting agency can view the entire market and thus determine a decisive factor for the purchase: the price.

8 Goldschmidt, E. Ph. Medieval Texts and Their First Appearance in Print. London, 1943, p. 40. 
Purchase in all subject fields will be greatly facilitated if full advantage is taken of the vast bibliographical knowledge of many members of the book trade. The reliable book dealer is the library's best and most efficient friend. $\mathrm{He}$ will call to our attention new publications from countries whose national biblographies appear either late or incomplete, he will search for outof-print items, and he is our ally in the fight against forgery. Practically every rare book which is no longer in its original binding must be carefully examined. Two incomplete copies of the same edition may have been used to produce a complete one, or facsimilies may have been substituted for some missing pages. Rigorous examination of small details will frequently suffice to expose the truth. Difference in paper, if not explained by the printing history of the book, change in the form of small defects, like worm-holes and water stains or their sudden disappearance will arouse our suspicion. The library may nevertheless decide to buy these items if the content, rarity and price should warrant it.

The situation with outright forgeries of an entire book, however, is quite different. Fortunately some examples of this type are known and well described. Some forgers try to place reprints on the market as originals by cutting out or erasing the colophon which bears the reprint date. A good example is Soliman and Persida of I 599, which had been reprinted by J. Smeeton in 1815 . A careful bibliographical identification combined with a critical examination of paper and typography will generally expose the reprint.

A much more difficult case is the identification to the Boccaccio edition printed by Giunta in Florence in 1527 . The book was reprinted in Venice at the beginning of the XVIII century by using XVI century paper and the original Giunta types. Only a careful bibliographical analysis will detect the reprint. Of similar nature is Cellini's autobiography of 1728 . Of XIX century origin are the famous $\mathrm{W}$ ise forgeries and the many Columbus letters of 1494 which run the gamut from crude attempts to superb examples of the forger's craft.

Many bibliographies are too expensive to be duplicated and will be in the main library only. Therefore it is fair to assume that the acquisition librarian has best access to all bibliographies in the library's holdings. He will be an avid reader of all national bibliographies, publishers' announcements and dealers' catalogs. It is a special reading technique which the book selecting bibliographer uses, a rapid and highly concentrated one. Every entry is under full scrutiny for a split second. It is evaluated instantaneously and, if rejected, immediately forgotten. With a thrill comparable only to the hunter's emotions on stalking his quarry, the bibliographer will be on the look-out for a desirable acquisition with all senses fully alerted. Like Anatole France's Silvestre Bonnard, he will readily admit: "I opened a book which I read with the greatest interest, it was a catalog of manuscripts."

Subject bibliographies, especially those which have been compiled for acquisition purposes are an excellent buying guide and indispensable for the systematic growth of a collection and for the filling in of gaps. The purchase of books still in print can be completely based on such a list; however, the acquisition of out-of-print material will generally originate from available offers. To work exclusively from desiderata lists would be slow and expensive.

What is the purpose of this bibliographical work? Obviously, and fortunately, we cannot buy everything which is being published or comes on the market. Comprehensive purchases are technically quite simple; the selection is the difficult and intellectually challenging task. A laconic 
interpretation of the selection policy for a research library was given by Dr. Wilmans, director of the Prussian State Library to the head of his acquisition department: "Buy documentary material." 9 The generally accepted definition will include the following groups: bibliographies, sources and all monographs which have more than ephemeral value either because of the new research they contain or because of a new presentation of known facts. The instructional and research needs of the individual institution will control closer selection within the above framework.

The acquisition librarian will first satisfy immediate needs, but then he will go beyond the requirements of the faculty. By paying close attention to new fields of research and new methods of investigation he will try to anticipate the requests of the subject specialist.

The significant position of the acquisition librarian as coordinator of purchases in all subject fields is at the same time the source of his greatest weakness. Although he may be a scholar in his own right in one sub-

'Handbuch der Bibliothekswissenschaften, herausgegeben von Fritz Milkau. Leipzig, 1933. Vol. 11, p. 139 . ject field, he will know next to nothing in some branches of learning and will be an amateur at the very best in other disciplines. His bibliographical experience will permit him to make many fairly reliable guesses, but it is not a full substitute for subject knowledge. Being fully aware of his own shortcomings, he will take advantage of the campus telephone on his desk. His foremost obligation is to convince the faculty of his institution of his eagerness to serve them, his appreciation of their advice and suggestions, his willingness to learn and his sincere interest in the growth of the library. $\mathrm{He}$ will then enjoy the enthusiastic support of his faculty and well exemplify Pierce Butler's resounding phrase: "In this age of specialization the librarian alone of all scholars is in a position to see both scientific and humanistic scholarship in the same perspective. Therefore it might seem that the librarian's chief and peculiar office is to promote in modern society a rational equilibrium and a mutual respect between these two forms of intellectual culture." 10

10 Butler, Pierce. "The Research Worker's Approach to Books, the Humanist," in The Acquisition and Cataloging of Books. Chicago, University of Chicago Press, 1940 , p. 283.

\section{Cooperation or Suffocation}

\section{(Continued from page 199 )}

When these bright days come, the work of the librarian and the administrator will change its nature. The college president and librarian can abandon the effort to outdistance their competitors in size. Instead they will devote their efforts to the improvement of quality and to the main- tenance of a library that is truly contemporary.

When we shall have a network of regional libraries effectively related to a national library and to the libraries of the world, I do not know. But I commend this dream to the librarians. 